\title{
KEMAMPUAN BERPIKIR ALJABAR SISWA SMP DALAM MENYELESAIKAN MASALAH MATEMATIKA DITINJAU DARI PERBEDAAN JENIS KELAMIN
}

\author{
Anggi Hardianti \\ Pendidikan Matematika, Fakultas Matematika dan Ilmu Pengetahuan Alam, Universitas Negeri Surabaya \\ Email: anggihardianti16030174061@mhs.unesa.ac.id
}

\author{
Ika Kurniasari \\ Pendidikan Matematika, Fakultas Matematika dan Ilmu Pengetahuan Alam, Universitas Negeri Surabaya \\ Email: ikakurniasari@unesa.ac.id
}

\begin{abstract}
Abstrak
Aljabar merupakan salah satu materi matematika yang wajib dipelajari oleh siswa, karena materi ini mempunyai keterkaitan dengan materi matematika yang lain misalnya kalkulus, geometri, statistika dan peluang, dan lain sebagainya. Kemampuan berpikir aljabar siswa perlu dikembangkan dengan cara melatih siswa berpikir aljabar. Kemampuan berpikir aljabar adalah kesanggupan siswa berpikir matematis yang meliputi generalisasi, abstraksi, berpikir analitis, berpikir dinamis, pemodelan, dan organisasi. Kemampuan berpikir aljabar siswa tentunya berbeda-beda. Perbedaan tersebut dipengaruhi oleh kemampuan matematika siswa dan jenis kelamin. Penelitian ini merupakan penelitian deskriptif dengan pendekatan kualitatif dengan tujuan untuk mendeskripsikan kemampuan berpikir aljabar siswa SMP dalam menyelesaikan masalah matematika ditinjau dari perbedaan jenis kelamin. Metode pengumpulan data melalui tes tertulis dan wawancara. Subjek penelitian yaitu satu siswa laki-laki dan satu siswa perempuan dengan kemampuan matematika tinggi yang setara. Hasil penelitian ini menujukkan perbedaan kemampuan berpikir aljabar siswa laki-laki dan siswa perempuan. Terdapat perbedaan kemampuan berpikir aljabar siswa laki-laki dan perempuan pada aktivitas generalisasi dengan indikator dapat menentukan suku berikutnya berdasarkan pola yang diperoleh, siswa laki-laki dengan cara menggambar sedangkan siswa perempuan dengan cara mendata. Selanjutnya pada aktivitas berpikir analitis dengan indikator menentukan nilai yang tidak diketahui dari sebuah persamaan, siswa laki-laki menggunakan cara mencoba-coba sedangkan siswa perempuan dengan cara aljabar.
\end{abstract}

Kata kunci : Kemampuan berpikir aljabar, masalah matematika, perbedaan jenis kelamin

\section{Abstract}

Algebra is one of the mathematical material which must be studied by students, because this material has links with other mathematical material such as calculus, geometry, statistics, probability and etc. Students' algebraic thinking skills need to be developed by training students to think algebra. Algebraic thinking ability is the ability of students to think mathematically which includes generalization, abstraction, analytic thinking, dynamic thinking, modeling, and organization. Students algebraic thinking abilities are certainly different. The difference is influenced by students mathematical abilities and gender. This research is a descriptive study with a qualitative approach that aims to describe the algebraic thinking ability of junior high school students in solving mathematical problems in terms of gender differences. The data collection methods are through written tests and interviews. The research subjects were one male student and one female student with high mathematical abilities. The results of this study show the different algebraic thinking abilities of male and female student. There is a difference in the algebraic thinking ability of male and female student in generalization with indicator that can determine the next syllable based on the patters obtained, male student by drawing while female student by recording. Furthermore, in analytic thinking activities with indicator can determine the unknown value of an equation, male student use trial and error while female student use algebraic methods.

Keywords : Algebraic thinking ability, mathematical problems, gender differences 


\section{PENDAHULUAN}

Aljabar merupakan materi baru dan salah satu materi wajib yang diajarkan kepada siswa. Berdasarkan Permendikbud No. 24 Tahun 2016, materi aljabar mulai diajarkan ketika Kelas VII semeter 1. Aljabar sering dimaknai sebagai bahasa simbol dan relasi. (Krismanto, 2004)

Aljabar merupakan salah satu cabang matematika yang wajib dipelajari karena dapat berguna dalam kehidupan. Hal tersebut sejalan dengan Suhaedi (2013) yang menyatakan bahwa aljabar merupakan salah satu materi yang penting dikuasai oleh siswa, karena secara implisit maupun eksplisit digunakan dalam kehidupan sehari-hari. Selanjutnya NCTM (2000) menyatakan bahwa kompetensi aljabar penting dalam kehidupan ketika dewasa, baik di tempat kerja maupun sebagai persiapan pendidikan tinggi.

Namun masih banyak siswa yang mengalami kesulitan dalam menyelesaikan soal terkait aljabar. Hal ini sejalan dengan Kieran (2004) yang menyatakan ketika masa transisi dari aritmatika ke aljabar membutuhkan banyak penyesuaian, kesulitan dialami oleh semua siswa bahkan bagi siswa yang sudah mahir dalam aritmatika, sehingga mereka banyak melakukan kesalahan. Linsell (2008) berpendapat bahwa aljabar sulit dipahami oleh siswa.

Kemampuan berpikir aljabar siswa perlu dikembangkan dengan cara melatih siswa berpikir aljabar. Kemampuan berpikir aljabar merupakan hal yang sangat penting dan mendasar dalam menyelesaikan masalah terkait aljabar. Lew (2004) berpendapat bahwa "Success in algebra depends on at least six kinds of mathematical thinking abilities as follows: generalization, abstraction, analytic thinking, dynamic thinking, modeling, and organization". Maksud dari pendapat Lew yaitu keberhasilan siswa dalam aljabar bergantung pada enam jenis berpikir matematis, meliputi generalisasi, abstraksi, berpikir analitis, berpikir dinamis, pemodelan, dan organisasi. Berpikir matematis dalam aljabar yang kemudian disebut berpikir aljabar dan tiap-tiap aktivitas berpikir aljabar mempunyai indikator pencapaiannya sendiri-sendiri. Dengan demikian, kemampuan berpikir aljabar merupakan kesanggupan siswa dalam mencapai indikator dari tiap-tiap aktivitas berpikir aljabar.

Kemampuan berpikir aljabar dapat muncul dari diri seseorang jika mereka diberi masalah. Masalah dalam matematika adalah suatu persoalan atau pertanyaan yang bersifat menantang yang tidak dapat diselesaikan dengan prosedur yang sudah biasa dilakukan/yang sudah diketahui (Polya, 1973). Masalah yang sesuai untuk menggali kemampuan berpikir aljabar siswa yaitu masalah matematika yang melibatkan konsep aljabar, kemudian siswa diminta untuk menyelesaikan masalah tersebut.

Dalam menyelesaikan masalah matematika, tiap siswa memiliki kemampuan yang berbeda-beda. Perbedaan ini salah satunya karena faktor jenis kelamin. Jenis kelamin dibedakan menjadi dua, yaitu laki-laki dan perempuan. Penelitian yang dilakukan oleh Atovigba, Vershima, O'Kwu, \& Ijenkeli (2012) menyatakan bahwa terdapat perbedaan pencapaian nilai siswa sekolah menengah di Nigeria dalam aljabar dan matematika lanjut berdasarkan perbedaan jenis kelamin. Selanjutnya, penelitian yang dilakukan Saputro dan Mampouw (2018) menyatakan bahwa adanya perbedaan kemampuan berpikir aljabar siswa laki-laki dan perempuan.

Berdasarkan uraian di atas, tujuan penelitian ini yaitu mendeskripsikan kemampuan berpikir aljabar siswa SMP dalam menyelesaikan masalah matematika ditinjau dari perbedaan jenis kelamin.

\section{METODE}

Penelitian ini bertujuan untuk mendeskripsikan kemampuan berpikir aljabar siswa SMP dalam menyelesaikan masalah matematika ditinjau dari perbedaan jenis kelamin. Berdasarkan tujuan penelitian, maka penelitian ini merupakan jenis penelitian deskriptif dengan pendekatan kualitatif. Penelitian ini menggunakan dua jenis instrumen yaitu instrumen utama adalah peneliti sendiri, dan instrumen pendukung adalah tes kemampuan matematika, tes kemampuan berpikir aljabar, dan pedoman wawancara. Data yang diperoleh dalam penelitian ini yaitu hasil dari tes kemampuan berpikir aljabar dan hasil wawancara. Tes kemampuan berpikir aljabar dikerjakan oleh subjek terpilih dan selanjutnya dilakukan wawancara terhadap subjek tersebut. Tujuan wawancara untuk menggali informasi yang belum terungkap melalui tes tertulis.

Analisis data dalam penelitian ini ada tiga yaitu analisis data hasil tes kemampuan matematika, analisis data hasil tes kemampuan berpikir aljabar, dan analisis data hasil wawancara. Analisis data tes kemampuan matematika dilakukan dengan cara siswa dikelompokkan dalam tiga kategori berdasarkan nilai hasil tes kemampuan matematika. Menurut Permendikbud Nomor 23 Tahun 2016 tentang Standar Penilaian Pendidikan dan observasi nilai KKM di SMP tempat penelitian ini dilakukan, kategori kemampuan matematika siswa sebagai berikut: kemampuan tinggi jika $86 \leq$ nilaites $\leq 100$, kemampuan sedang jika $72 \leq$ nilaites $<86$, dan kemampuan rendah jika $0 \leq$ nilai tes $<72$. Analisis data tes kemampuan berpikir aljabar berdasarkan indikator kemampuan berpikir aljabar. 
Tabel 1. Indikator Kemampuan Berpikir Aljabar

\begin{tabular}{|c|c|}
\hline Berpikir Aljabar & $\begin{array}{c}\text { Indikator Kemampuan } \\
\text { Berpikir Aljabar }\end{array}$ \\
\hline \multirow[t]{2}{*}{ Generasional } & $\begin{array}{l}\text { 1. Dapat menemukan pola } \\
\text { umum dari hubungan } \\
\text { antar objek yang diberikan }\end{array}$ \\
\hline & $\begin{array}{l}\text { 2. Dapat menentukan suku } \\
\text { berikutnya berdasarkan } \\
\text { pola yang diperoleh }\end{array}$ \\
\hline Abstraksi & $\begin{array}{l}\text { Dapat menyatakan sesuatu } \\
\text { yang belum diketahui nilainya } \\
\text { dengan menggunakan variabel }\end{array}$ \\
\hline Berpikir Dinamis & $\begin{array}{l}\text { Dapat menganalisis hubungan } \\
\text { antara bilangan dalam pola } \\
\text { untuk menentukan suku } \\
\text { berikutnya dengan berbagai } \\
\text { cara penyelesaian }\end{array}$ \\
\hline Pemodelan & $\begin{array}{l}\text { Dapat menyatakan } \\
\text { permasalahan ke dalam model } \\
\text { matematika }\end{array}$ \\
\hline Berpikir Analitis & $\begin{array}{l}\text { Dapat menentukan nilai yang } \\
\text { tidak diketahui dari sebuah } \\
\text { pemodelan }\end{array}$ \\
\hline Organisasi & $\begin{array}{l}\text { Dapat membuat tabel yang } \\
\text { menggambarkan situasi } \\
\text { masalah dan hubungan antara } \\
\text { kondisi dari masalah } \\
\text { keseluruhan. }\end{array}$ \\
\hline
\end{tabular}

Analisis data wawancara dilakukan melalui tahapan reduksi data, penyajian data, dan penarikan kesimpulan (Miles \& Huberman, 2014).

\section{HASIL DAN PEMBAHASAN}

Masalah matematika yang digunakan dalam penelitian ini sebagai berikut.

Kerjakan soal di bawah ini dengan cermat. Perhatikan gambar di bawah ini

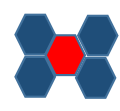

Pola Ke-1

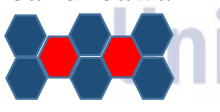

Pola Ke-2

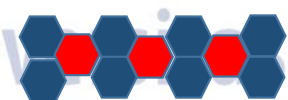

Pola Ke-3
1. Jika banyaknya segienam merah adalah 12 , berapa banyak segienam biru yang dibutuhkan untuk membuat susunan seperti pada gambar di atas? Berikan alasanmu.

2. Jika banyaknya segienam merah adalah $p$, berapa banyak segienam biru yang dibutuhkan untuk membuat susunan seperti pada gambar di atas? Berikan alasanmu.

3. Jika banyaknya segienam biru adalah 132 , berapa banyak segienam merah yang dibutuhkan untuk membuat susunan seperti pada gambar di atas? Berikan alasanmu.

Berdasarkan analisis data hasil tes kemampuan berpikir aljabar dan wawancara subjek laki-laki dan perempuan didapatkan deskripsi kemampuan berpikir aljabar siswa SMP dalam menyelesaikan masalah matematika ditinjau dari perbedaan jenis kelamin sebagai berikut.

1. Kemampuan Berpikir Aljabar Siswa Laki-laki SMP dalam Menyelesaikan Masalah Matematika

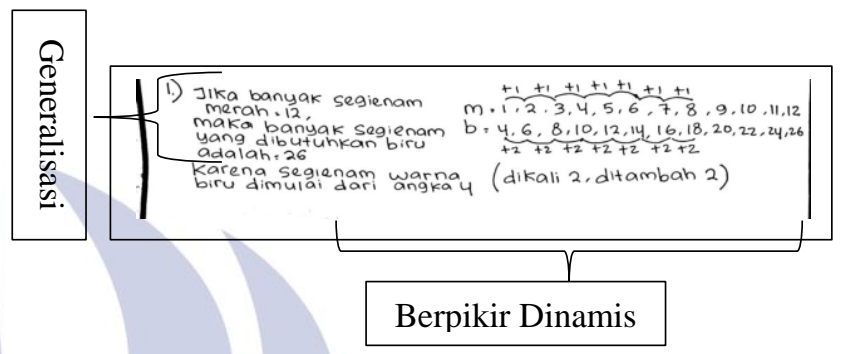

Gambar 1. Hasil Tes Tertulis Siswa Laki-laki Masalah Nomor 1

Berdasarkan analisis hasil tes kemampuan berpikir aljabar dan wawancara masalah nomor 1, siswa laki-laki dapat memahami maksud soal nomor 1 dengan baik. Siswa laki-laki dapat menjelaskan maksud dari masalah dengan bahasanya sendiri. Hal pertama yang dilakukan siswa laki-laki yaitu mengamati pola ke-1, pola ke-2, dan pola ke-3, kemudian siswa laki-laki dapat menemukan pola. Pola yang diperoleh yaitu selisih banyaknya segienam merah dari pola sebelumnya ke pola selanjutnya adalah 1 dan selisih banyaknya segienam biru dari pola sebelumnya ke pola selanjutnya adalah 2. Aktivitas ini masuk dalam aktivitas generalisasi. Selanjutnya siswa dapat menentukan banyaknya segienam biru jika diketahui banyaknya segienam merah adalah 12 . Siswa memperoleh banyaknya segienam biru adalah 26. Aktivitas ini masuk dalam aktivitas generalisasi. Selanjutnya subjek menentukan banyaknya segienam biru jika diketahui segienam merah adalah 12 dengan cara menggambar segienam sebanyak 12 dengan diikuti segienam biru juga seperti pada pola ke 1, 2, dan 3. Aktivitas ini masuk dalam aktivitas berpikir dinamis.

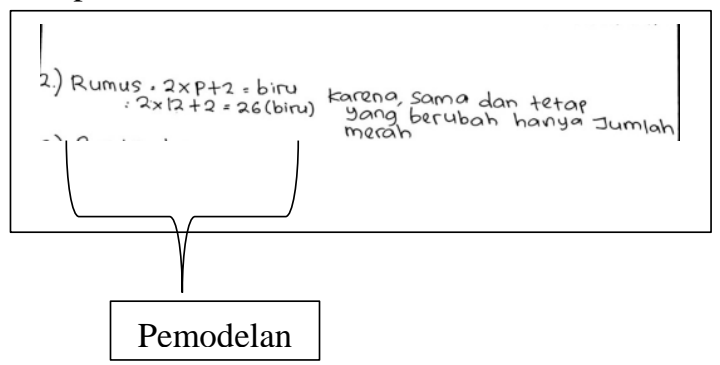

Gambar 2. Hasil Tes Tertulis Siswa Laki-laki Masalah Nomor 2 
Berdasarkan analisis hasil tes kemampuan berpikir aljabar dan wawancara masalah nomor 2, siswa laki-laki dapat memahami maksud dari masalah nomor 2 dengan baik. Siswa laki-laki dapat menjelaskan maksud dari masalah dengan bahasanya sendiri. Hal pertama yang dilakukan siswa yaitu memahami maksud dari $p$. Siswa dapat menjelaskan bahwa $p$ itu menyatakan banyaknya segienam merah. $p$ disini dapat digunakan untuk mencari banyaknya segienam biru sesuai dengan yang ditanyakan pada masalah nomor 2. Kemudian siswa dapat menyatakan banyaknya segienam biru dengan $2 \times p+2$. Aktivitas ini masuk dalam aktivitas abstraksi. Selanjutnya siswa dapat menentukan banyaknya segienam biru dengan cara melihat contoh pola ke-1, 2, dan 3. Siswa membagi contoh pola ke-1, 2, dan 3 dalam 2 bagian yaitu bagian atas dan bagian bawah. Untuk bagian atas, siswa menyatakan bahwa banyaknya segienam biru itu sama dengan banyaknya segienam merah lalu ditambah 1. Hal tersebut juga berlaku untuk bagian bawah yaitu banyaknya segienam biru sama dengan banyaknya segienam merah ditambah 1 . Pada masalah nomor 2 telah diketahui banyaknya segienam merah $=p$, sehingga banyaknya segienam biru yang bagian atas adalah $p+1$, selanjutnya banyaknya segienam biru yang bawah juga $p+1$. Jadi, banyaknya segienam biru adalah $p+1+p+$ $1=2 \times p+2$. Aktivitas ini masuk dalam aktivitas pemodelan.

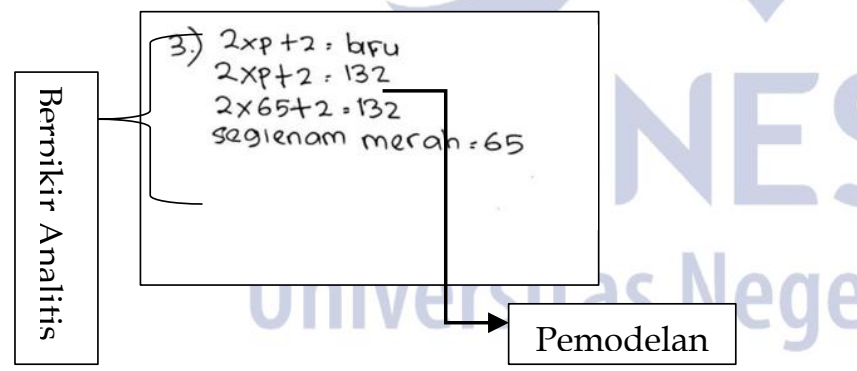

Gambar 3. Hasil Tes Tertulis Siswa Laki-laki Masalah Nomor 3

Berdasarkan analisis hasil tes kemampuan berpikir aljabar dan wawancara masalah nomor 3, siswa laki-laki dapat memahami maksud dari masalah nomor 3 dengan baik. Siswa laki-laki dapat menjelaskan maksud dari masalah dengan bahasanya sendiri. Hal pertama yang dilakukan siswa yaitu menentukan pemodelan jika diketahui banyaknya segienam biru adalah 132 . Pemodelan yang diperoleh siswa yaitu $2 \times p+2=132$. Siswa memperoleh persamaan tersebut dari jawaban masalah nomor 2. Aktivitas ini masuk dalam aktivitas pemodelan. Selanjutnya siswa dapat menentukan banyaknya segienam merah yaitu 65 . Aktivitas ini masuk dalam aktivitas berpikir analitis.

2. Kemampuan Berpikir Aljabar Siswa Perempuan SMP dalam Menyelesaikan Masalah Matematika

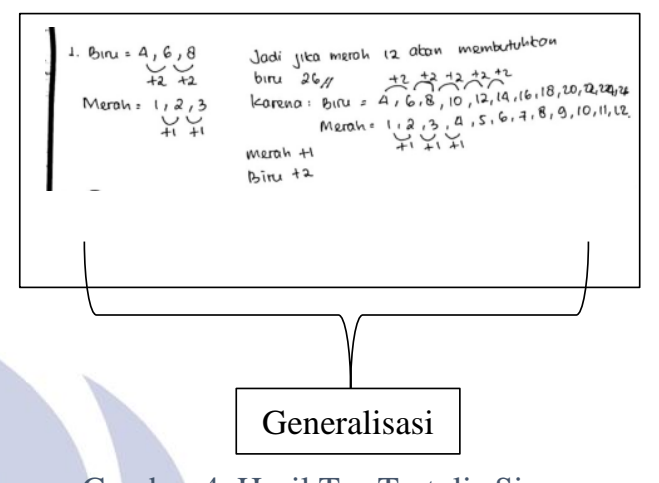

Gambar 4. Hasil Tes Tertulis Siswa Perempuan Masalah Nomor 1

Berdasarkan analisis hasil tes kemampuan berpikir aljabar dan wawancara masalah nomor 1, siswa perempuan dapat memahami maksud soal nomor 1 dengan baik. Siswa perempuan dapat menjelaskan maksud dari masalah dengan bahasanya sendiri. Hal pertama yang dilakukan siswa perempuan yaitu mengamati pola ke-1, pola ke-2, dan pola ke-3, kemudian siswa perempuan dapat menemukan pola. Pola yang diperoleh yaitu segienam merah dari pola sebelumnya ke pola selanjutnya mempunyai selisih 1 dan segienam biru dari pola sebelumnya ke pola selanjutnya mempunyai selisih 2. Aktivitas ini masuk dalam aktivitas generalisasi. Selanjutnya siswa dapat menentukan banyaknya segienam biru jika diketahui banyaknya segienam merah adalah 12. Siswa memperoleh banyaknya segienam biru adalah 26. Aktivitas ini masuk dalam aktivitas generalisasi.

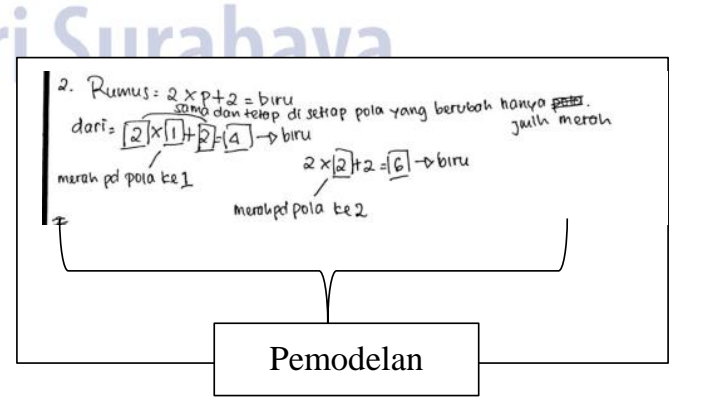

Gambar 5. Hasil Tes Tertulis Siswa Perempuan Masalah Nomor 2

Berdasarkan analisis hasil tes kemampuan berpikir aljabar dan wawancara masalah nomor 2, siswa perempuan dapat memahami maksud dari masalah 
nomor 2 dengan baik. Siswa perempuan dapat menjelaskan maksud dari masalah dengan bahasanya sendiri. Hal pertama yang dilakukan siswa yaitu memahami maksud dari $p$. Siswa dapat menjelaskan bahwa $p$ itu menyatakan banyaknya segienam merah. $p$ disini dapat digunakan untuk mencari banyaknya segienam biru sesuai dengan yang ditanyakan pada masalah nomor 2, kemudian siswa dapat menyatakan banyaknya segienam biru dengan $2 \times p+2$. Aktivitas ini masuk dalam aktivitas abstraksi. Selanjutnya siswa dapat menentukan banyaknya segienam biru dengan cara mencoba-coba dan dengan mensubstitusikan sebarang bilangan jika dikali dengan banyaknya segienam merah dan selanjutnya ditambah dengan sebarang bilangan lainnya akan diperoleh banyaknya segienam biru sesuai dengan pola yang telah ditemukan. Kemudian, siswa memperoleh pola umum untuk mengetahui banyaknya segienam biru yaitu $2 \times p+2$. Aktivitas ini masuk dalam aktivitas pemodelan.

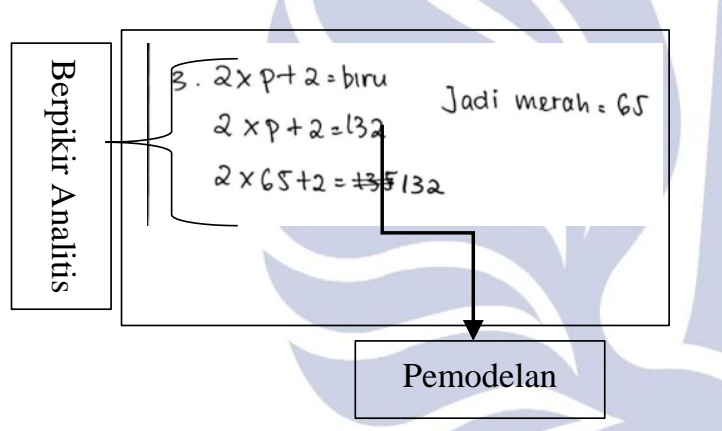

Gambar 6. Hasil Tes Tertulis Siswa Perempuan Masalah Nomor 3

Berdasarkan analisis hasil tes kemampuan berpikir aljabar dan wawancara masalah nomor 3, siswa perempuan dapat memahami maksud dari masalah nomor 3 dengan baik. Siswa perempuan dapat menjelaskan maksud dari masalah dengan bahasanya sendiri. Hal pertama yang dilakukan siswa yaitu menentukan pemodelan jika diketahui banyaknya segienam biru adalah 132 . Pemodelan yang diperoleh siswa yaitu $2 \times p+2=132$. Siswa memperoleh pemodelan tersebut dari jawaban masalah nomor 2. Aktivitas ini masuk dalam aktivitas pemodelan. Selanjutnya siswa dapat menentukan banyaknya segienam merah yaitu 65 . Aktivitas ini masuk dalam aktivitas berpikir analitis.

\section{PENUTUP}

\section{Simpulan}

Berdasarkan hasil analisis data dan pembahasan terkait hasil tes kemampuan berpikir aljabar, sehingga dapat dideskripsikan kemampuan berpikir aljabar siswa SMP dalam menyelesaikan masalah matematika ditinjau dari perbedaan jenis kelamin sebagai berikut.

\section{Kemampuan Berpikir Aljabar Siswa Laki-laki SMP dalam Menyelesaikan Masalah Matematika}

Pada aktivitas generalisasi kemampuan berpikir aljabar yang dicapai siswa yaitu dapat menemukan pola umum dari hubungan antar objek yang diberikandan dapat menentukan suku berikutnya berdasarkan pola yang diperoleh. Selanjutnya aktivitas berpikir dinamis, kemampuan berpikir aljabar yang dicapai siswa yaitu dapat menganalisis hubungan antara bilangan dalam pola untuk menentukan suku berikutnya dengan berbagai cara penyelesaian. Pada aktivitas abstraksi, kemampuan berpikir aljabar yang dicapai siswa yaitu dapat menyatakan sesuatu yang belum diketahui nilainya dengan menggunakan variabel. Pada aktivitas pemodelan, kemampuan berpikir aljabar yang dicapai siswa yaitu dapat menyatakan permasalahan dalam model matematika. Pada aktivitas berpikir analitis, kemampuan berpikir aljabar yang dicapai siswa yaitu dapat menentukan nilai yang tidak diketahui dari sebuah pemodelan.

\section{Kemampuan Berpikir Aljabar Siswa Perempuan SMP} dalam Menyelesaikan Masalah Matematika

Pada aktivitas generalisasi kemampuan berpikir aljabar yang dicapai siswa yaitu dapat menemukan pola umum dari hubungan antar objek yang diberikan. Dari temuan pola umum tersebut dan dapat menentukan suku berikutnya berdasarkan pola yang diperoleh. Selanjutnya pada aktivitas abstraksi, kemampuan berpikir aljabar yang dicapai siswa yaitu dapat menyatakan sesuatu yang belum diketahui nilainya dengan menggunakan variabel. Pada aktivitas pemodelan, kemampuan berpikir aljabar yang dicapai siswa yaitu dapat menyatakan permasalahan dalam model matematika. Selanjutnya pada aktivitas berpikir analitis, kemampuan berpikir aljabar yang dicapai siswa yaitu dapat menentukan nilai yang tidak diketahui dari sebuah pemodelan.

\section{Saran}

Berdasarkan penelitian yang telah dilakukan, saran yang diberikan peneliti sebagai berikut.

1. Penelitian ini bertujuan untuk mendeskripsikan kemampuan berpikir aljabar siswa SMP dalam menyelesaikan masalah matematika ditinjau dari perbedaan jenis kelamin. Dalam penelitian ini terdapat perbedaan kemampuan aljabar siswa laki-laki dan perempuan dalam menyelesaikan masalah matematika, terutama siswa perempuan yang tidak dapat menganalisis hubungan antara bilangan dalam pola untuk menentukan suku berikutnya dengan berbagai cara penyelesaian 
sehingga indikator kemampuan berpikir aljabar pada aktivitas berpikir dinamis tidak muncul. Oleh karena itu sebaiknya guru memperhatikan konsep aljabar siswa dan melatih siswa dalam menyelesaikan masalah matematika dengan berbagai cara penyelesaian.

2. Ketika melakukan wawancara, sebaiknya mencari tempat yang jauh dari keramaian. Hal tersebut dikarenakan agar mendapatkan hasil rekaman yang jelas dan siswa serta peneliti dapat berkonsentrasi dalam melakukan wawancara.

\section{DAFTAR PUSTAKA}

Atovigba, M. V. (2012). Gender Trends in Nigerian School Students' Performance in Algebra. Research Journal of Mathematics and Statistic, Vol 4(2): pp 42-44.

Kemendikbud. (2016). Permendikbud Nomor 24 Tahun 2016 tentang Kompetensi Inti dan Kompetensi Dasar pada Kurikulum 2013 pada Pendidikan Dasar dan Pendidikan Menengah. Jakarta: Kemendikbud.

Kieran, Carolyn. (2004). Algebraic Thinking in the Early Grades : What is it. The Mathematics Educator, Vol. 8 (1): pp. 139 - 151.

Krismanto, A. (2004). Aljabar. Yogyakarta: Pusat Pengembangan Penataran Guru (PPPG) Matematika.
Lew, Hee-Chan. (2004). Developing Algebraic Thinking in Early Grades: Case Study of Korean Elementary School Mathematics. The Mathematics Educator, Vol. 8 (1): pp 88-106.

Linsell, Chris. (2008). Solving Equations: Students' Algebraic Thinking. (Online), (https://www.researchgate.net/publication/25330 7691 Solving

Miles \& Huberman, A. (2014). Analisis Data Kualitatif. Terjemahan Tjetjep Rohendi Rohidi. Jakarta: UI Press.

NCTM. (2000). Principle and Standard for School Mathematics. Reston: The National Council of Teacher Mathematics.

Permendikbud. 2016. Peraturan Menteri Pendidikan dan Kebudayaan Nomor 23 Tahun 2016 Tentang Standar Penilaian Pendidikan.

Polya, G. (1973). How to Solve it. Princeton: Princeton University Press.

Saputro, G. B., \& Mampouw, H. L. (2018). Profil Kemampuan Berpikir Aljabar Siswa SMP pada Materi Persamaan Linear Satu Variabel Ditinjau dari Perbedaan Gender. Jurnal Numeracy, Vol. 5, No. 1, 77 - 90 .

Suhaedi, D. (2013). Peningkatan Kemampuan Komunikasi Matematis, Berpikir Aljabar, dan Disposisi Matematis Siswa SMP Melalui Pendekatan Pendidikan Matematika Realistik. Disertasi tidak diterbitkan. Bandung: Universitas Pendidikan Indonesia. 